\title{
NREL
}

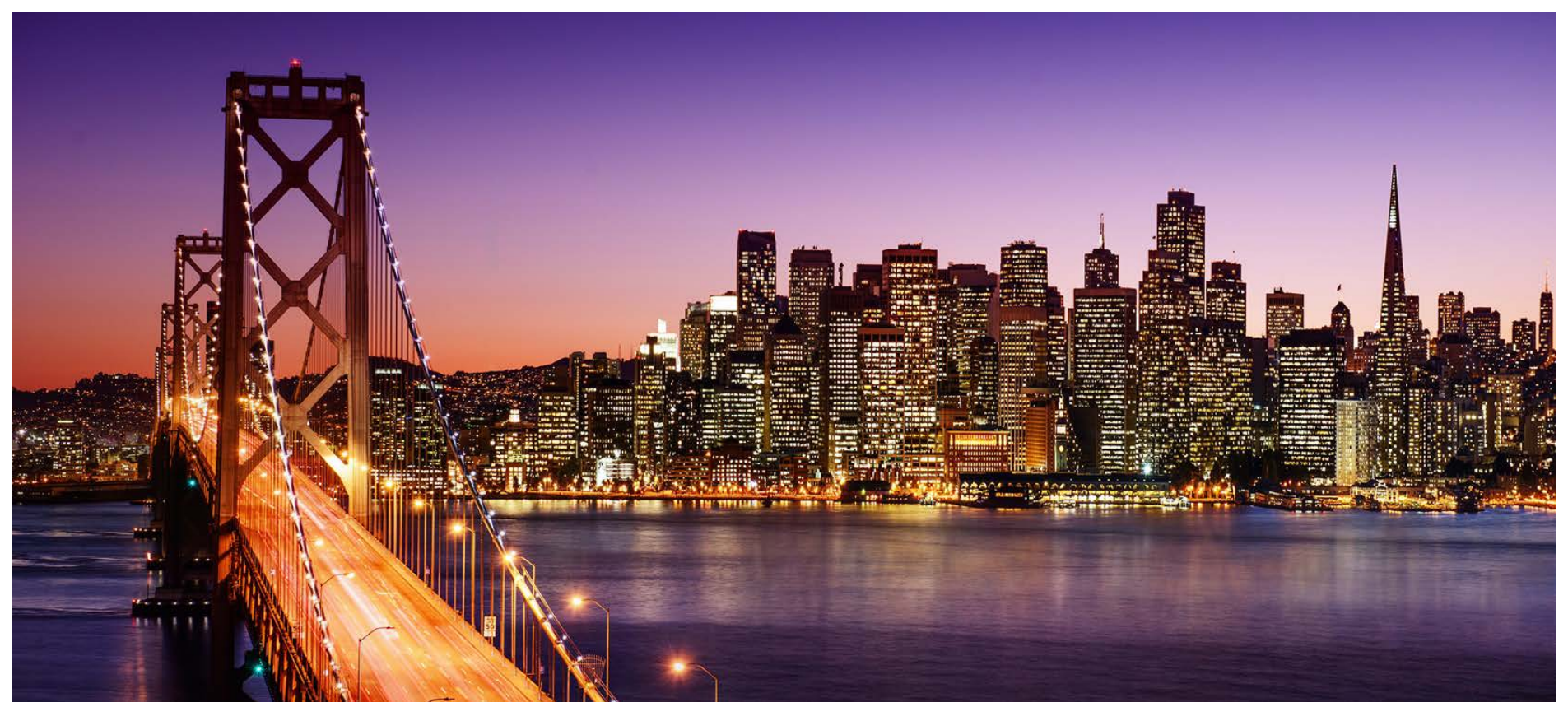

\section{Workshop on Fundamental Needs for Dynamic and Interactive Thermal Storage Solutions for Buildings}

Sumanjeet Kaur, ${ }^{1}$ Marcus Bianchi, ${ }^{2}$ and Nelson James ${ }^{3}$

1 Lawrence Berkeley National Laboratory

2 National Renewable Energy Laboratory

3 Oak Ridge Institute for Science and Education

NREL is a national laboratory of the U.S. Department of Energy Office of Energy Efficiency \& Renewable Energy

Operated by the Alliance for Sustainable Energy, LLC

This report is available at no cost from the National Renewable Energy Laboratory (NREL) at www.nrel.gov/publications.
Technical Report NREL/TP-5500-76701 June 2020 


\title{
2019 Workshop on Fundamental Needs for Dynamic and Interactive Thermal Storage Solutions for Buildings
}

\author{
Sumanjeet Kaur, ${ }^{1}$ Marcus Bianchi, ${ }^{2}$ and Nelson James ${ }^{3}$
}

1 Lawrence Berkeley National Laboratory

2 National Renewable Energy Laboratory

3 Oak Ridge Institute for Science and Education

\section{Suggested Citation}

Kaur, Sumanjeet, Marcus Bianchi, and Nelson James. 2020. 2019 Workshop on

Fundamental Needs for Dynamic and Interactive Thermal Storage Solutions for Buildings.

Golden, CO: National Renewable Energy Laboratory. NREL/TP-5500-76701.

https://www.nrel.gov/docs/fy20osti/76701.pdf.

NREL is a national laboratory of the U.S. Department of Energy Office of Energy Efficiency \& Renewable Energy Operated by the Alliance for Sustainable Energy, LLC

This report is available at no cost from the National Renewable Energy Laboratory (NREL) at www.nrel.gov/publications.

Contract No. DE-AC36-08GO28308
Technical Report NREL/TP-5500-76701 June 2020

National Renewable Energy Laboratory 15013 Denver West Parkway Golden, CO 80401

303-275-3000 • www.nrel.gov 


\section{NOTICE}

This work was authored in part by the National Renewable Energy Laboratory, operated by Alliance for Sustainable Energy, LLC, for the U.S. Department of Energy (DOE) under Contract No. DE-AC36-08GO28308. Funding provided by the U.S. Department of Energy Office of Energy Efficiency and Renewable Energy Building Technologies Office. The views expressed herein do not necessarily represent the views of the DOE or the U.S. Government.

This report is available at no cost from the National Renewable Energy Laboratory (NREL) at www.nrel.gov/publications.

U.S. Department of Energy (DOE) reports produced after 1991 and a growing number of pre-1991 documents are available free via www.OSTI.gov.

Cover Photo: iStock 476881195.

NREL prints on paper that contains recycled content. 


\section{Acknowledgments}

Thank you to all the invited speakers and participants in the 2019 Workshop on Fundamental Needs for Dynamic and Interactive Thermal Storage Solutions for Buildings. Their contributions, insights, and willingness to share their experiences about the use of thermal energy storage in buildings made the event successful.

We thank the breakout session leads, Gao Liu, Chris Dames, Judith Vidal, and Anubhav Jain, for facilitating discussions and documenting the findings. In addition, we thank Ravi Prasher and the Lawrence Berkeley National Laboratory (LBNL) for hosting the workshop in Berkeley. We thank Marie Butson for organizing the meeting and facilitating communication.

We also gratefully acknowledge the financial support from LBNL, which enabled us to organize and conduct this workshop. 


\section{List of Acronyms}

CEC

DOE

HVAC

LBNL

LCOS

NREL

NSF

ORNL

PCM

R\&D

TES
California Energy Commission

U.S. Department of Energy

heating, ventilating, and air conditioning

Lawrence Berkeley National Laboratory

levelized cost of storage

National Renewable Energy Laboratory

National Science Foundation

Oak Ridge National Laboratory

phase change materials

research and development

thermal energy storage 


\section{Executive Summary}

The 2019 Workshop on Fundamental Needs for Dynamic and Interactive Thermal Storage Solutions for Buildings was held at Lawrence Berkeley National Laboratory (LBNL) in Berkeley, California, on November 19-20, 2019. The workshop convened 47 individuals involved in thermal, building, and materials science to present and discuss the use of thermal energy storage (TES) associated with buildings. The goals of the event were to revisit recent breakthroughs and identify future research opportunities in scientific areas related to:

1. Dynamically tunable thermal storage materials that can modify their switching temperature or characteristics to operate optimally in both summer and winter;

2. Thermal circuits elements (analogous to electrical circuits), diodes, switches, and transistors, which could control directional heat and mass transfer and thus provide management over the timing of charging or discharging;

3. Characterization tools and techniques to understand fundamental issues, such as supercooling, metastable phases, slow kinetics, and poor cyclability in TES materials; and

4. Expedite discovery of new materials using computational materials design for thermal energy solutions, combinatorial synthesis, and high throughput characterization.

The workshop comprised a half day of invited talks followed by breakout sessions. The invited talks reviewed the rationale for use of TES in buildings, presented a parallel with electrochemical storage and concentrating solar power thermal storage, and had discussions on materials discovery and characterization. The bulk of the workshop was spent in the breakout sessions where the workshop participants were split into four groups, which were identified to increase the competitiveness of TES technologies: (1) Efficiency; (2) Utilization; (3) Lifetime; and (4) Computational Discovery of Thermal Storage Materials. During the breakout sessions, participants were asked to identify Major Topics, Technological Barriers, Transformational Research Topics, Potential Science Impacts, and Impact on Energy Technology.

The first section of this report, based on Karma Sawyer's ${ }^{1}$ invited talk, provides background for the use of TES in buildings. The main part of the report details the findings from the breakout sessions. A final section describes some of the recommendations based on the findings from the breakout sessions.

The workshop identified the following needs:

1. Methods to estimate TES efficiency

2. Effective ways to improve the utilization and flexibility of TES

3. Dynamic tunable storage integrated with thermal switches for better utilization, load flexibility, and integration with the grid

4. Removal of lifetime barriers that impact the performance of TES systems

5. Methods to accurately predict lifetime

\footnotetext{
${ }^{1}$ Program Manager of Emerging Technologies, Building Technologies Office, U.S. Department of Energy
} 
6. Algorithms (e.g., machine learning) to better manage thermal storage assets and understand economic impacts of new storage technologies

7. Data sets to validate theoretical models or machine learning methods.

A consensus among attendees is the desire to create a larger effort with a consortium of national laboratories, universities, and other research organizations on TES. 


\section{Table of Contents}

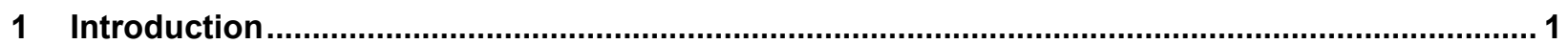

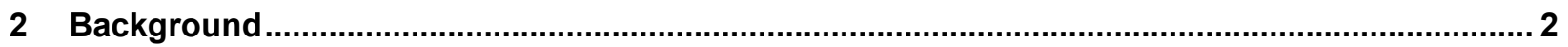

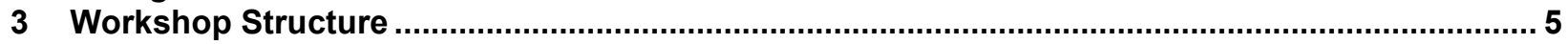

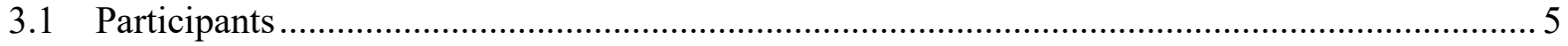

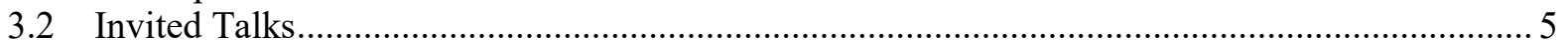

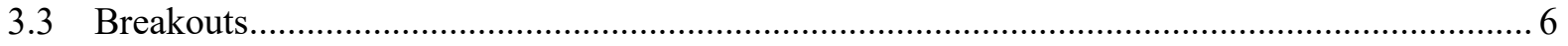

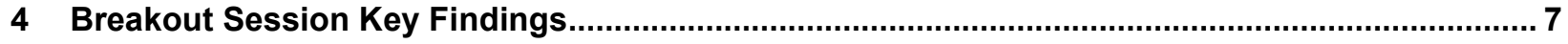

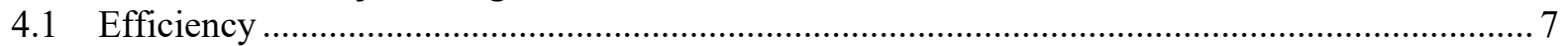

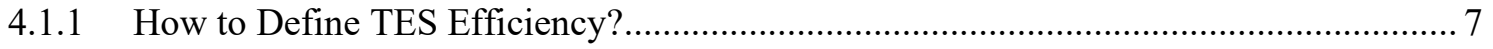

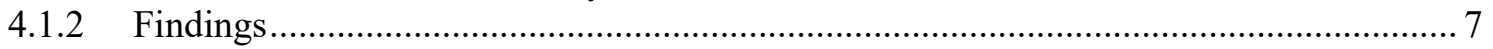

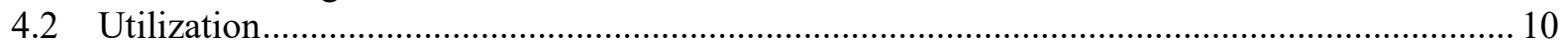

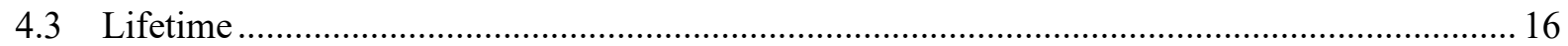

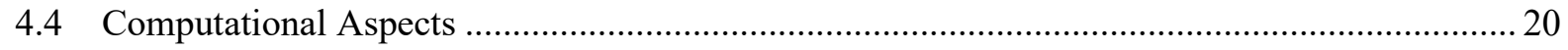

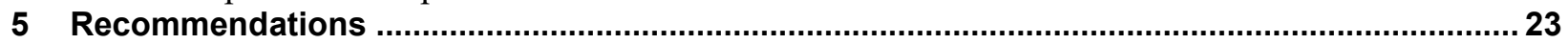

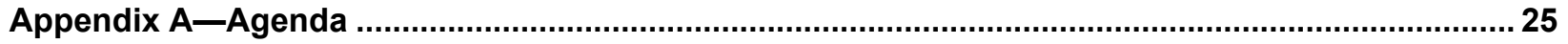

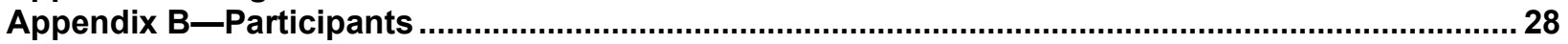

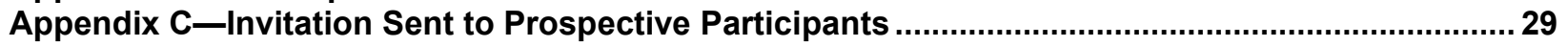

Workshop on Fundamental Needs for Dynamic and Interactive Thermal Storage Solutions for

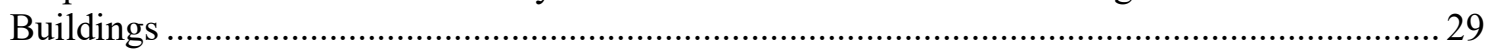




\section{List of Figures}

Figure 1. Variation in end-use electrical consumption during peak on off-peak hours for residential and

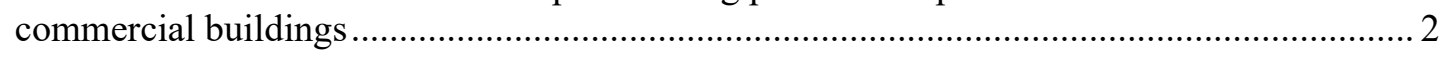

Figure 2. Depiction of integrated energy storage ecosystem ........................................................ 3

\section{List of Tables}

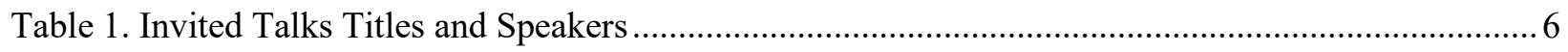

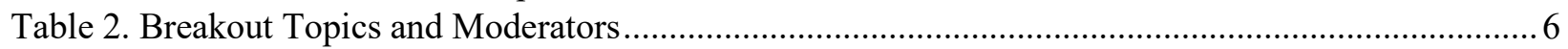

Table 3. TES Efficiency: Major Topics, Technological Barriers, Transformational Research Topics,

Potential Science Impacts, and Impact on Energy Technology ............................................ 8

Table 4. Utilization: Major Topics, Technological Barriers, Transformational Research Topics, Potential

Science Impacts, and Impact on Energy Technology...................................................... 11

Table 5. Lifetime: Major Topics, Technological Barriers, Transformational Research Topics, Potential

Science Impacts, and Impact on Energy Technology....................................................... 17

Table 6. Computational Aspects: Major Topics, Technological Barriers, Transformational Research

Topics, Potential Science Impacts, and Impact on Energy Technology.................................2 21

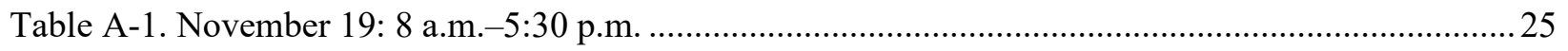

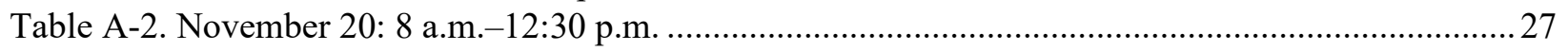

Table B-1. List of Participants Who Attended the Workshop ............................................................. 28 


\section{Introduction}

This report presents the findings of the 2019 Workshop on Fundamental Needs for Dynamic and Interactive Thermal Storage Solutions for Buildings. The workshop was sponsored by and held at Lawrence Berkeley National Laboratory (LBNL) in Berkeley, California, November 19-20, and convened 47 experts in thermal, building, and materials sciences. The following sections detail the rationale, structure, and findings of the workshop. 


\section{Background}

The electrical grid is facing significant transformations. What used to predominantly be a onedirectional system, where centralized plants deliver power to end users, is rapidly evolving. As more variable renewable and distributed generation sources are integrated into the electrical grid, the difficulties of reliably matching supply and demand increase. Additionally, growing peak demand and transmission and distribution constraints are also stressing the electrical grid. Energy storage can play a key role in helping to balance supply and demand of electricity. Buildings consume nearly $75 \%$ of all the electricity generated in the United States and are responsible for a comparably significant portion of peak power demands (U.S. EIA 2019). Figure 1 displays the variation in end-use electrical consumption for residential and commercial buildings.

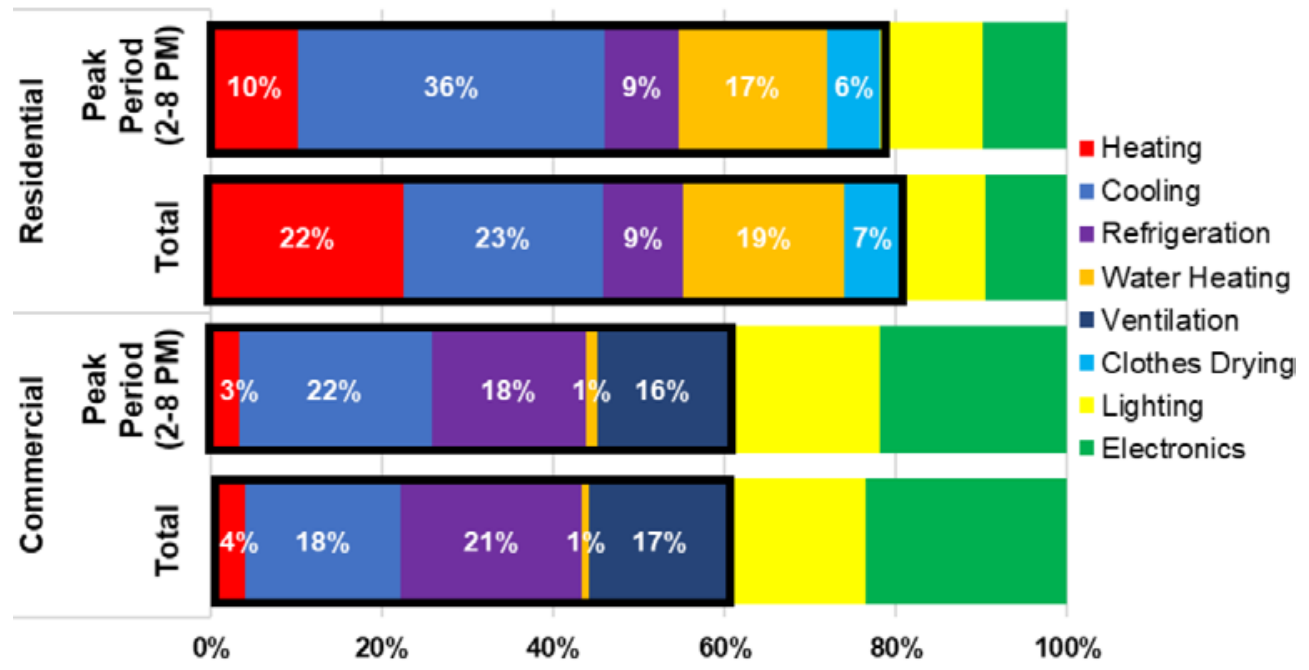

Figure 1. Variation in end-use electrical consumption during peak on off-peak hours for residential and commercial buildings

Figure from U.S. Department of Energy 2019

Many of the solutions that have been investigated for building energy storage have traditionally been thermal mass (e.g., adobe) or phase change (ice storage) and, more recently, electrochemical (e.g., batteries). Because $50 \%$ or more of the energy consumed in buildings can be for thermal end uses, thermal energy storage (TES) can also play an important role in facilitating a balanced energy system that is efficient, resilient, and affordable. Systems utilizing hot/chilled water, ice, or other materials have been sold commercially. While readily available, deployment of these traditional TES systems in buildings is still limited. For envelope-based systems, limited adoption is primarily because they charge and discharge passively in response to ambient temperatures and can only shift to off-peak hours either in heating or cooling modes, not both. More generally adoption is limited due to most phase change materials (PCMs) suffer from issues such as supercooling, broad transition temperatures, low energy density, poor heat transfer, degradation with cycling, and high prices. These problems collectively limit increased deployment of TES technologies.

In November 2019, LBNL and the National Renewable Energy Laboratory (NREL) cohosted a two-day workshop to explore ways to revolutionize TES technologies. For TES to make a more significant impact on the energy ecosystem, disruptive solutions are needed that enable control of 
charging and discharging, as well as address the major shortcomings of existing TES technologies. Stakeholders with a diverse range of expertise, from material science to system integration, participated to ensure recommendations would encompass solutions at all scales.

Batteries and TES technologies should not be looked at as competitors. Rather, they should be treated as complementary systems that can be optimized to work together to service building needs, help integrate distributed energy resources (see Figure 2 for a depiction), and provide services to the electrical grid. Batteries have several advantages from the ability to supply critical electrical loads to the constant price reductions born out of focused research efforts. Leveraging the extensive work that has gone into electrochemical energy storage, insights can be translated to aid TES technology development.

Four primary opportunity areas were identified for developments that are needed to increase the competitiveness of TES technologies. These consisted of capital cost reductions, as well as efficiency, utilization, and lifetime improvements.

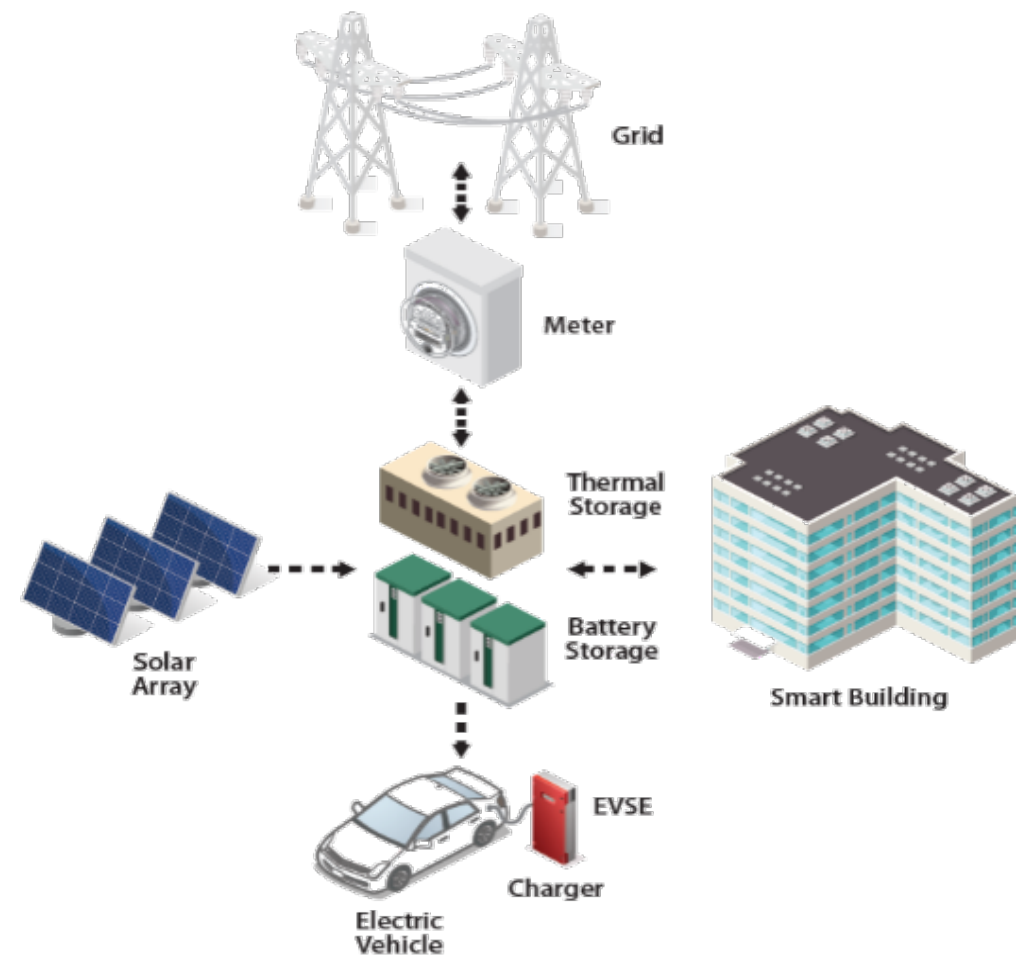

Figure 2. Depiction of integrated energy storage ecosystem Figure by NREL

\subsection{Capital Cost}

Many TES approaches require large installations to achieve meaningful amounts of energy storage. This leads to increased capital cost due to increased storage materials as well as materials to house and insulate the storage medium. Water is the most abundant thermal storage material in use today due to its low cost and moderate energy density. Alternative materials have been explored for thermal storage, including various thermophysical- and thermochemical-based transformations. To reduce the size of storage installations, materials with both high energy and power densities for thermal storage are needed. Computationally guided discovery of new 
materials could aid in the identification of new molecules, materials, and chemistries with high energy density. Also, use of combinatorial synthesis and high throughput characterization for TES materials could expedite realization of these new materials.

\subsection{Efficiency}

Regardless of what materials are used for TES, some interface between the thermal storage material and the heat source or sink is necessary. As energy is transferred through different forms and across boundaries, losses occur. Thermal resistances and bridges can increase the amount of energy required to charge the storage medium, as well as reduce the energy and power delivery capacity of the thermal storage during discharge. Improved designs and materials may be needed to increase the overall round-trip efficiency of TES.

\subsection{Utilization}

When thermal loads are present, the increased ability to control when thermal energy is charged/discharged and at what temperatures this occurs can greatly increase the usefulness of thermal storage technologies. PCMs can store appreciable amounts of thermal energy. The phase transition of these materials typically occurs in a narrow band of temperatures. In most building applications, the PCM must be chosen such that it provides cooling or heating use. In much of the United States there is both a heating and cooling season. This means that at times of the year, when the temperature does not cross over the transition temperature range, the PCM is only storing energy in sensible form or a partially melted state. This translates to the storage medium not being fully utilized. Dynamically tunable thermal storage materials that can modify their switching temperature or characteristics to operate optimally in both summer and winter can significantly increase the utilization of the TES.

Another challenge to TES utilization is the fact that heat flows tend to occur through passive components with the primary means of control being inputs from devices controlled through electrical switches. A revolution in electrical devices occurred with the introduction of nonlinear components such as diodes and transistors. Thermal circuits elements (analogous to electrical circuits) diodes, switches, and transistors, which could control directional heat and mass transfer and thus provide management over the timing of charging or discharging, could lead to a paradigm shift in thermal energy utilization.

\subsection{Lifetime}

One of the most vital aspects of any investment in building technologies is that it must last for multiple years (ideally the lifetime of the building or equipment that the TES is integrated with). The longer the storage systems lasts, the more useful charge and discharge cycles the owner will get out of the investment. Though they still have their own degradation mechanisms, TES materials are believed to be able to outlast electrochemically based battery technologies. Use of new characterization tools and techniques to understand and solve the fundamental issues, such as the presence of non-equilibrium phases, slow kinetics, and poor cyclability in TES devices, can significantly improve the economics of these technologies. 


\section{Workshop Structure}

The workshop was conducted over two days at LBNL. As discussed previously, four primary opportunity areas were identified for developments needed to increase the competitiveness of TES technologies. Breakout sessions were organized around these four topics:

1. Efficiency

2. Utilization

3. Lifetime

4. Computational Discovery of Thermal Storage Materials.

\subsection{Participants}

The organizers identified individuals from academia, industry, and research institutions, representing a large spectrum of areas that are directly or indirectly involved in TES research. Representatives from the U.S. Department of Energy (DOE), California Energy Commission (CEC), and the National Science Foundation (NSF) attended the workshop. The attendees have background in one of the following areas:

- Thermal storage

- Building science

- Nanoscale thermal transport

- Materials science

- Mechanical cooling and heating systems (heating, ventilating, and air conditioning [HVAC]). Appendix B presents a list of the participants and their affiliation.

\subsection{Invited Talks}

On the first day, after the welcome from Mike Witherell (LBNL Director) and Ravi Prasher (LBNL Associate Director), a series of invited talks were delivered to establish the current state of the art and objectives of the workshop. Table 1 lists the subjects and speakers invited to present at the workshop.

Karma Sawyer started by setting the stage for the need of TES. Robin Goodhand presented the efforts by the CEC in energy storage. Robert Kostecki provided a historical perspective of electrochemical storage and how some of the lessons could be applied to TES research. Judith Vidal described the uses of TES in concentrating solar power. Anubhav Jain discussed the process of computational material discovery and how it could apply to TES materials. Kyle Gluesenkamp, Navin Kumar, and Eli Rotenberg all discussed characterization techniques for TES materials. 
Table 1. Invited Talks Titles and Speakers

\begin{tabular}{|l|l|}
\hline Title & Speaker \\
\hline $\begin{array}{l}\text { Scientific and Technological Challenges in } \\
\text { Thermal Storage-Why are we here? Review of } \\
\text { goals/objectives, challenges, research and } \\
\text { development (R\&D) needs, and opportunities }\end{array}$ & $\begin{array}{l}\text { Karma Sawyer, Program Manager, Emerging } \\
\text { Technologies, Office of Energy Efficiency and } \\
\text { Renewable Energy, DOE }\end{array}$ \\
\hline Energy Systems Integration and Energy Storage & $\begin{array}{l}\text { Robin Goodhand, Electric Generation System } \\
\text { Specialist, CEC }\end{array}$ \\
\hline History of Electrochemical Storage & $\begin{array}{l}\text { Robert Kostecki, Scientific Division Director, } \\
\text { Energy Storage Group, LBNL }\end{array}$ \\
\hline $\begin{array}{l}\text { Evolution, Progress, and Challenges of Thermal } \\
\text { Storage in Concentrated Solar Power }\end{array}$ & $\begin{array}{l}\text { Judith Vidal, Group Manager, Building Energy } \\
\text { Science, NREL }\end{array}$ \\
\hline Computational Material Discovery & $\begin{array}{l}\text { Anubhav Jain, Chemist Staff Scientist/Engineer, } \\
\text { Applied Energy Materials Group, LBNL }\end{array}$ \\
\hline $\begin{array}{l}\text { Challenges with Current Characterization } \\
\text { Techniques for Thermal Energy Storage Materials }\end{array}$ & $\begin{array}{l}\text { Kyle Gluesenkamp, Senior R\&D Scientist, and } \\
\text { Navin Kumar, postoctoral researcher, Oak Ridge } \\
\text { National Laboratory (ORNL) }\end{array}$ \\
\hline $\begin{array}{l}\text { New Characterization Techniques for Thermal } \\
\text { Energy Storage Materials }\end{array}$ & $\begin{array}{l}\text { Eli Rotenberg, Senior Scientist, Program Lead } \\
\text { Angle-Resolved Photoemission Spectroscopy } \\
\text { (ARPES), Photon Science Operations, LBNL }\end{array}$ \\
\hline NSF Perspective on Thermal Energy Storage & $\begin{array}{l}\text { Ying Sun, Program Director, Thermal Transport } \\
\text { Processes, Engineering/Chemical, } \\
\text { Bioengineering, Environmental and Transport } \\
\text { Systems (ENG/CBET), NSF }\end{array}$ \\
\hline
\end{tabular}

\subsection{Breakouts}

Marcus Bianchi and Sumanjeet Kaur briefly introduced the structure of the breakout sessions, creating teams in the following areas with the associated moderators (Table 2).

Table 2. Breakout Topics and Moderators

\begin{tabular}{|l|l|}
\hline Topic & Moderator \\
\hline Efficiency & Gao Liu, LBNL \\
\hline Utilization & Chris Dames, UC Berkeley \\
\hline Lifetime & $\underline{\text { Judith Vidal, NREL }}$ \\
\hline Computational Discovery of Thermal Storage Materials & Anubhav Jain, LBNL \\
\hline
\end{tabular}

Based on their backgrounds, we created groups of participants for each breakout topic for the first two hours of discussions. While the moderators stayed with the same topics, in the second breakout meeting (one and a half hours), attendees were encouraged to change breakout topics to increase the generation of new concepts and ideas. 


\section{Breakout Session Key Findings}

\subsection{Efficiency}

During the breakout sessions of both the first and second days, the groups discussed different aspects of efficiency. Here is a summary of the discussion.

\subsubsection{How to Define TES Efficiency?}

- How to connect microscale material properties measured by differential scanning calorimetry to bulk material properties?

- At which level should efficiency be defined? System level, materials plus encapsulation, or in a building installation?

- Is time scale important for measuring and defining the efficiency? Daily versus seasonal?

- Does power density need to be considered when defining efficiency?

- Does hysteresis need to be considered? How does hysteresis interplay with power impact the efficiency measurement?

- How does transition temperature range impact the efficiency?

- Should it be defined as life cycle efficiency (first cycle to last cycle)?

- What mathematical definitions should be used to define efficiency of TES?

- Need measurement standardization for the efficiency from micro to system levels to assist and stimulate the development of this area.

\subsubsection{Findings}

Table 3 shows the summary of results of this breakout session as organized by Dr. Gao Liu (moderator). Two major themes were discussed by the participants: interface thermal contact resistance and reversibility. Two critical highlights:

- The community needs a comprehensive standard in targets and measurement methods to better quantify the "building thermal efficiency." These definitions can help to bridge fundamental thermal science to the applied building efficiency. It is an important component to an applied oriented research program.

- More focused fundamental research needs to be performed on the understanding of thermal transport in composite materials and their interfaces and tune-able materials as such forwardlooking directions. 
Table 3. TES Efficiency: Major Topics, Technological Barriers, Transformational Research Topics,

Potential Science Impacts, and Impact on Energy Technology

\begin{tabular}{|c|c|c|c|c|}
\hline Major Topics & Technological Barriers & $\begin{array}{l}\text { Transformational Research } \\
\text { Topics }\end{array}$ & Potential Science Impacts & $\begin{array}{l}\text { Impact on Energy } \\
\text { Technology }\end{array}$ \\
\hline $\begin{array}{l}\text { Transport at } \\
\text { Interfaces } \\
\text { (Thermal and } \\
\text { Mass) }\end{array}$ & $\begin{array}{l}\text { 1. Poor thermal and mass } \\
\text { transport at interfaces } \\
\text { 2. Lack of understanding of } \\
\text { changes in contact areas } \\
\text { and morphologies at } \\
\text { interfaces with cycling } \\
\text { and effect of these on } \\
\text { transport } \\
\text { 3. Lack of predictive } \\
\text { models at system levels } \\
\text { which incorporates } \\
\text { interfaces and changes } \\
\text { at interfaces } \\
\text { 4. Difficult to generalize, as } \\
\text { the transport has strong } \\
\text { dependence on } \\
\text { geometry. }\end{array}$ & \begin{tabular}{|ll} 
1. & Heat loss factor and \\
transport at the interface \\
2. Impedance factors \\
3. \\
Moisture and water in \\
4VAC \\
4. \\
5. \\
6. \\
Thentach and and mormal and mass \\
transport.
\end{tabular} & $\begin{array}{l}\text { 1. Understand heat } \\
\text { transport at the atomic } \\
\text { and interface level } \\
\text { 2. Move the knowledge } \\
\text { level from ideal system } \\
\text { to practical hybrid } \\
\text { system, such as large } \\
\text { scale and composite } \\
\text { materials } \\
\text { 3. Develop predictive } \\
\text { mathematical models for } \\
\text { the hybrid materials and } \\
\text { system. }\end{array}$ & $\begin{array}{l}\text { 1. Improve efficiency } \\
\text { 2. Controlled large-scale } \\
\text { processing of the } \\
\text { interface } \\
\text { 3. Accurate prediction of } \\
\text { the system performance } \\
\text { in multiple length scale } \\
\text { and in system level } \\
\text { 4. Better overall control in } \\
\text { the materials and system } \\
\text { level. }\end{array}$ \\
\hline Reversibility & $\begin{array}{l}\text { 1. Phase segregation of the } \\
\text { thermal storage material } \\
\text { 2. Need for better } \\
\text { understanding of the } \\
\text { phase evolution, namely } \\
\text { the effect of rate of } \\
\text { cooling and heating } \\
\text { 3. Is it thermodynamically } \\
\text { limited or kinetically } \\
\text { limited process? } \\
\text { 4. Lack of understanding of } \\
\text { supercooling* at system } \\
\text { level. }\end{array}$ & 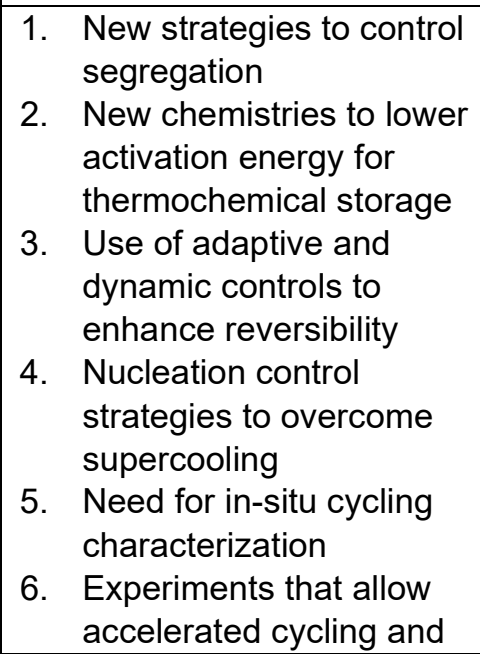 & $\begin{array}{l}\text { 1. Reversibility of PCMs } \\
\text { 2. Stability of materials } \\
\text { under repeated thermal } \\
\text { cycles } \\
\text { 3. Thermal degradation } \\
\text { mechanisms and } \\
\text { prevention } \\
\text { 4. Nucleation and } \\
\text { supercooling at large } \\
\text { scale. }\end{array}$ & $\begin{array}{l}\text { 1. At the large scale, } \\
\text { allowing construction of } \\
\text { the thermal storage } \\
\text { system with predictive } \\
\text { and long lifetime } \\
\text { 2. At a device level, thermal } \\
\text { diode and switch } \\
\text { 3. Circular economy based } \\
\text { on regeneration of the } \\
\text { storage materials. }\end{array}$ \\
\hline
\end{tabular}




\begin{tabular}{|c|c|c|c|c|}
\hline Major Topics & Technological Barriers & $\begin{array}{l}\text { Transformational Research } \\
\text { Topics }\end{array}$ & Potential Science Impacts & $\begin{array}{l}\text { Impact on Energy } \\
\text { Technology }\end{array}$ \\
\hline & & $\begin{array}{l}\text { quantification of } \\
\text { degradation and/or } \\
\text { determination of } \\
\text { degradation mechanisms } \\
\text { in situ. }\end{array}$ & & \\
\hline $\begin{array}{l}\text { Material } \\
\text { Properties, for } \\
\text { Example: Type of } \\
\text { Storage (Sensible, } \\
\text { Latent, } \\
\text { Thermochemical), } \\
\text { Transition } \\
\text { Temperature } \\
\text { Range, Hysteresis }\end{array}$ & $\begin{array}{l}\text { 1. Need for systematic } \\
\text { material characterization } \\
\text { and standard reporting of } \\
\text { materials properties in } \\
\text { literature } \\
\text { 2. Can new scientific } \\
\text { approaches yield step } \\
\text { function changes in } \\
\text { energy density? } \\
\text { 3. Can hysteresis losses be } \\
\text { minimized in PCMs to } \\
\text { maximize round-trip } \\
\text { efficiency? }\end{array}$ & $\begin{array}{l}\text { 1. Explore thermal storage } \\
\text { including various } \\
\text { thermophysical- and } \\
\text { thermochemical-based } \\
\text { transformations } \\
\text { 2. Explore materials using } \\
\text { computational methods } \\
\text { to aid in the discovery of } \\
\text { new TES materials, } \\
\text { which have both high } \\
\text { energy and power } \\
\text { densities for thermal } \\
\text { storage. A potential path } \\
\text { to achieve this includes } \\
\text { the design of new } \\
\text { molecules/materials/che } \\
\text { mistries with high energy } \\
\text { density }\end{array}$ & $\begin{array}{l}\text { Lead to the development of } \\
\text { new materials }\end{array}$ & $\begin{array}{l}\text { 1. Accelerated materials } \\
\text { discovery could be a } \\
\text { game-changer for TES } \\
\text { as it can significantly } \\
\text { reduce the footprint of } \\
\text { storage } \\
\text { 2. Standardized reporting } \\
\text { of materials properties } \\
\text { will accelerate the } \\
\text { research. }\end{array}$ \\
\hline
\end{tabular}




\subsection{Utilization}

Prof. Chris Dames moderated this session. The discussions during this breakout session can be grouped under the categories of temporal, such as tunable PCMs and thermal switch, spatial and crosscutting ideas, including complex optimization and codesign.

1. PCM with tunable phase transition temperature. High risk and fundamentally challenging, but high impact if successful. Probably many ways of attacking this problem (e.g., voltage-controlled phase change temperature).

2. Thermal switches for building applications. This is relatively difficult, especially from the perspective of plausible cost and scalability. For envelope integrated, the cost levels are quite challenging. Switching ratio and high off-state resistance are the leading technical challenges, along with cyclability. Can the interfacial thermal resistance be tuned to act as thermal switch? It remains to be seen if such ideas can be economically viable to achieve the metrics ultimately needed for buildings.

\section{Crosscutting}

A. System-level modeling and complex optimization, the co-design ideas. Need simple model building blocks to feed into the higher-level models. Can machine learning/artificial intelligence aspects be fruitful here?

B. High throughput metrology seems important. Also, this community might be ripe for some round-robin studies on relevant materials.

C. Composites to enhance the effective thermal conductivity, diffusivity, of TES

D. Innovative business models ("heating and cooling as a service")

E. Human comfort and psychological aspects (i.e., $\mathrm{T}_{\text {perceived }}$ not equal to $\mathrm{T}_{\text {actual }}$ ) are quite intriguing and worthy of research somewhere.

Table 4 shows the summary of results of this breakout session as organized by Prof. Chris

Dames. 
Table 4. Utilization: Major Topics, Technological Barriers, Transformational Research Topics,

Potential Science Impacts, and Impact on Energy Technology

\begin{tabular}{|c|c|c|c|c|}
\hline Major Topics & Technological Barriers & $\begin{array}{l}\text { Transformational } \\
\text { Research Topics }\end{array}$ & $\begin{array}{l}\text { Potential Science } \\
\text { Impacts }\end{array}$ & $\begin{array}{l}\text { Impact on Energy } \\
\text { Technology }\end{array}$ \\
\hline $\begin{array}{l}\text { Tunable Phase } \\
\text { Transition } \\
\text { Temperature (TPT) }\end{array}$ & $\begin{array}{l}\text { 1. PCM with dynamically tunable } \\
\text { TPT does not exist today } \\
\text { 2. Can we generate enough } \\
\text { enthalpy change }(\Delta \mathrm{H}) \text {, or, } \\
\text { more likely, entropy change } \\
(\Delta \mathrm{S}) \text { from external stimuli to } \\
\text { yield desirable }\left(\Delta \mathrm{T}_{\mathrm{PT}}\right) \text { (i.e., } 5- \\
\left.10^{\circ} \mathrm{C}\right) \text { ? } \\
\text { 3. What are the possible control } \\
\text { mechanisms to change the } \\
\text { TPT (pressure, electrical, } \\
\text { thermal, magnetic, optical)? } \\
\text { 4. What are the energy costs of } \\
\text { applying the external stimuli? } \\
\text { 5. How fast can we do it, and } \\
\text { what is the optimal time } \\
\text { scale? } \\
\text { 6. Could tunable transitions lead } \\
\text { to materials lifetime issues? }\end{array}$ & $\begin{array}{l}\text { 1. Identify the most } \\
\text { plausible mechanisms to } \\
\text { induce sufficiently large } \\
\left.\left(\Delta \mathrm{T}_{\mathrm{PT}}\right) \text { (i.e., } 5-10^{\circ} \mathrm{C}\right) \\
\text { 2. PCM with tunable } \Delta \mathrm{T}_{\mathrm{PT}} \\
\text { induced either } \\
\text { autonomously adaptive } \\
\text { to temperature and/or } \\
\text { humidity or by the most } \\
\text { suitable modes in the } \\
\text { building settings } \\
\text { (electrical?) } \\
\text { 3. Identify allotropic } \\
\text { materials with different } \\
\text { phase transitions (e.g., } \alpha \text {, } \\
\beta, \mathrm{v} \text { phases) } \\
\text { 4. Identify different phase } \\
\text { change mechanisms } \\
\text { (solid-solid, solid-liquid, } \\
\text { and so on) } \\
\text { 5. Minimize auxiliary } \\
\text { components for } \mathrm{T}_{\mathrm{PT}} \\
\text { control. }\end{array}$ & $\begin{array}{l}\text { 1. Since } \Delta T_{\mathrm{PT}}=\Delta \mathrm{H} / \Delta \mathrm{S} \text {, } \\
\text { fundamental } \\
\text { question is how to } \\
\text { tune and design to } \\
\text { get desirable and } \\
\text { tunable } \Delta \mathrm{T}_{\mathrm{PT}} \\
\text { 2. How narrow can be } \\
\Delta \mathrm{T}_{\mathrm{PT}} \\
\text { 3. Lead to development } \\
\text { of high-entropy } \\
\text { alloys. }\end{array}$ & $\begin{array}{l}\mathrm{PCM} \text { with } \triangle \mathrm{T}_{\mathrm{PT}} \text { can } \\
\text { significantly increase the } \\
\text { utilization of } \mathrm{PCM} \text { across } \\
\text { different time scales. For } \\
\text { example, tunable PCM can } \\
\text { be used both diurnal and } \\
\text { seasonal (summer versus } \\
\text { winter). }\end{array}$ \\
\hline Thermal Switch & $\begin{array}{l}\text { 1. Lack of thermal switches with } \\
\text { large switching ratio (5-10x) } \\
\text { for buildings applications } \\
\text { 2. Need for low thermal } \\
\text { conductance at off state (for }\end{array}$ & $\begin{array}{l}\text { 1. All solid-state switches } \\
\text { with low conductance } \\
\text { at off state (air-like } \\
\text { thermal conductivity) } \\
\text { 2. Reliable ( } 1,000 \text { to } \\
10,000 \text { cycles), }\end{array}$ & $\begin{array}{l}\text { 1. Reduce the lower } \\
\text { limit thermal } \\
\text { conductivity in solids } \\
\text { to yield air-like } \\
\text { thermal conductivity }\end{array}$ & $\begin{array}{l}\text { Efficient thermal switch can } \\
\text { greatly enhance the } \\
\text { utilization of TES and } \\
\text { reduce the building energy } \\
\text { load. }\end{array}$ \\
\hline
\end{tabular}




\begin{tabular}{|c|c|c|c|c|}
\hline Major Topics & Technological Barriers & $\begin{array}{l}\text { Transformational } \\
\text { Research Topics }\end{array}$ & $\begin{array}{l}\text { Potential Science } \\
\text { Impacts }\end{array}$ & $\begin{array}{l}\text { Impact on Energy } \\
\text { Technology }\end{array}$ \\
\hline & $\begin{array}{l}\text { thermal insulation application } \\
\text { in envelopes) } \\
\text { 3. Need for high thermal } \\
\text { conductance at on state (heat } \\
\text { dissipation applications) } \\
\text { 4. Need for optimization for cost, } \\
\text { speed, efficiency (energy } \\
\text { input for switch) } \\
\text { 5. Building-compatible switching } \\
\text { mechanism (electrical? } \\
\text { mechanical? magnetic? } \\
\text { optical?) } \\
\text { 6. If using mechanical contacts, } \\
\text { reliability of the contacts could } \\
\text { be an issue. If all solid state, } \\
\text { low conductance at off state } \\
\text { is difficult for all-solid-state } \\
\text { switches (amorphous limits } \\
\text { thermal conductivity). }\end{array}$ & $\begin{array}{l}\text { reversible thermal } \\
\text { switches with high } \\
\text { switching ratios (5-10x) } \\
\text { with low enough } \\
\text { conductance at off } \\
\text { state or high enough } \\
\text { conductance at on } \\
\text { state; } \\
\text { 3. Low cost thermal } \\
\text { switching mechanism } \\
\text { that is compatible with } \\
\text { building environment } \\
\text { 4. Highly reliable switches } \\
\text { based on mechanical } \\
\text { contacts? } \\
\text { 5. Exploit existing } \\
\text { materials with distinct } \\
\text { thermal conductivities } \\
\text { at different phases but } \\
\text { narrower phase } \\
\text { transition temperature } \\
\text { range is needed with } \\
\text { no hysteresis. }\end{array}$ & 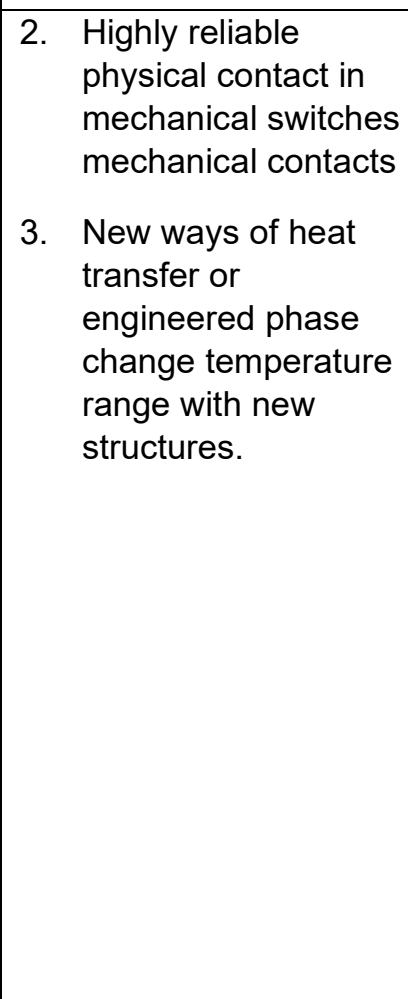 & \\
\hline $\begin{array}{l}\text { Spatial/Directional } \\
\text { Control }\end{array}$ & $\begin{array}{l}\text { 1. Difficulty in defining the scale } \\
\text { of spatial control } \\
\text { 2. How to do spatial control for } \\
\text { thermal services? } \\
\text { 3. Long-range (>1 mile) transfer } \\
\text { of heat because of being } \\
\text { inherently entropically } \\
\text { irreversible }\end{array}$ & 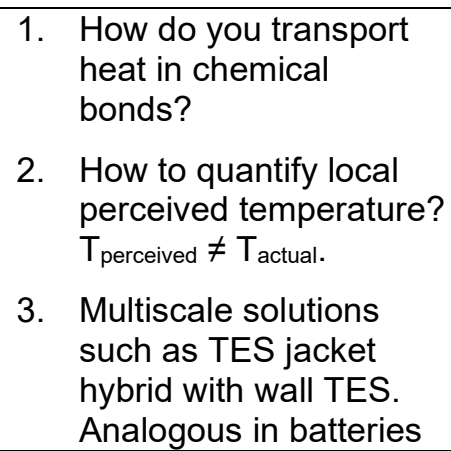 & 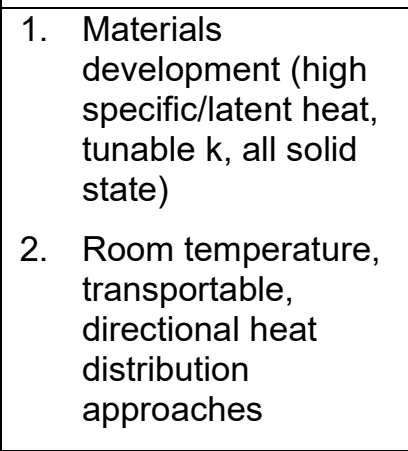 & $\begin{array}{l}15 \%-20 \% \text { energy savings } \\
\text { already exists for localized } \\
\text { heating in building [DELTA } \\
\text { program in ARPA-E]. } \\
\text { Potentially } 90 \% \text { energy } \\
\text { savings if we had human } \\
\text { space suit. }\end{array}$ \\
\hline
\end{tabular}




\begin{tabular}{|c|c|c|c|c|}
\hline Major Topics & Technological Barriers & $\begin{array}{l}\text { Transformational } \\
\text { Research Topics }\end{array}$ & $\begin{array}{l}\text { Potential Science } \\
\text { Impacts }\end{array}$ & $\begin{array}{l}\text { Impact on Energy } \\
\text { Technology }\end{array}$ \\
\hline & $\begin{array}{l}\text { 4. Quantification of the delivery } \\
\text { of heat locally } \\
\text { 5. Air as a heat-transfer fluid; } \\
\text { energy density is the issue } \\
\text { 6. Modularity and compactness } \\
\text { are still challenging. }\end{array}$ & $\begin{array}{l}\text { will be supercapacitor } \\
\text { hybrid with Pb-acid } \\
\text { 4. } \begin{array}{l}\text { Transportable and } \\
\text { noncontact heat } \\
\text { delivery (Radiative } \\
\text { heating/cooling and } \\
\text { evaporative cooling for } \\
\text { spatially controlled } \\
\text { heating) }\end{array} \\
\text { 5. Induction for human } \\
\text { body heating } \\
\text { 6. Flexibility in activation } \\
\text { and deactivation } \\
\text { 7. Reduction of loss in the } \\
\text { delivery of heat } \\
\text { 8. Potential of extreme } \\
\text { long distance (Use } \\
\text { thermochemical } \\
\text { materials for } \\
\text { intercontinental heat } \\
\text { storage and delivery, } \\
\text { vaccine cooling). }\end{array}$ & 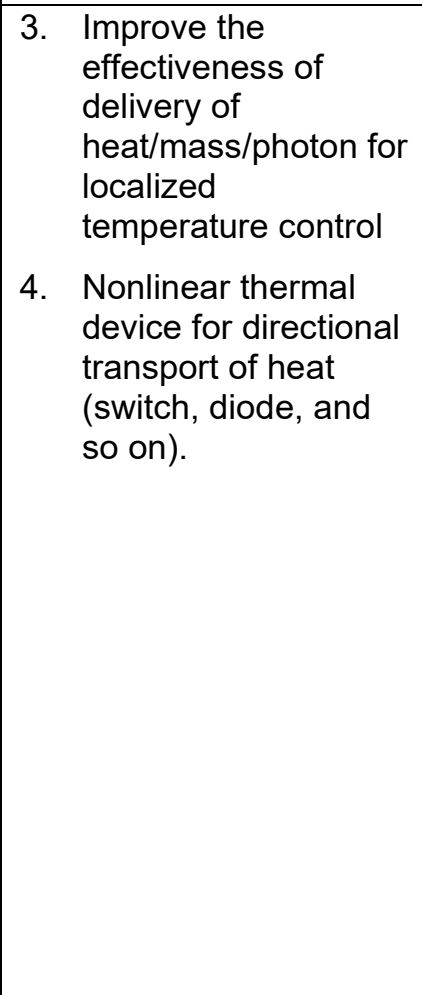 & \\
\hline Hybrid Systems & $\begin{array}{l}\text { 1. Low-delta T electric } \\
\text { generation efficiency } \\
\text { 2. Need to decouple electric and } \\
\text { thermal load/generation } \\
\text { 3. Lack of quantifying potential } \\
\text { 4. Lack of collaboration of } \\
\text { materials and thermal } \\
\text { researchers. }\end{array}$ & $\begin{array}{l}\text { 1. Ab-initio codesign of } \\
\text { materials and systems } \\
\text { 2. Equipment for heat } \\
\text { pump and heat engine: } \\
\text { Same or different? } \\
\text { 3. New materials to } \\
\text { enable low-dT high } \\
\text { efficiency power } \\
\text { generation }\end{array}$ & 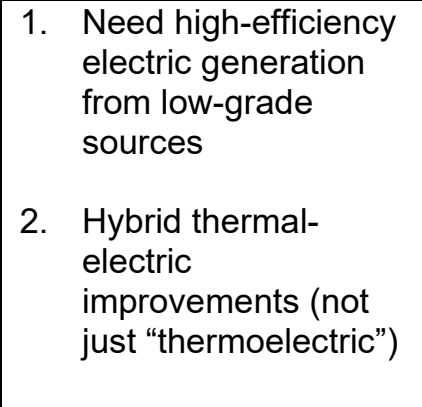 & $\begin{array}{ll}\text { 1. Improve energy } \\
\text { conversion efficiency } \\
\text { 2. Full usage of energy. } \\
\text { Reduce waste thermal } \\
\text { energy. }\end{array}$ \\
\hline
\end{tabular}




\begin{tabular}{|c|c|c|c|c|}
\hline Major Topics & Technological Barriers & $\begin{array}{l}\text { Transformational } \\
\text { Research Topics }\end{array}$ & $\begin{array}{l}\text { Potential Science } \\
\text { Impacts }\end{array}$ & $\begin{array}{l}\text { Impact on Energy } \\
\text { Technology }\end{array}$ \\
\hline & & $\begin{array}{l}\text { 4. Ripe for seedling } \\
\text { scoping study. }\end{array}$ & $\begin{array}{l}\text { 3. New more efficient } \\
\text { thermodynamic } \\
\text { processes for } \\
\text { thermal to electric } \\
\text { generation. }\end{array}$ & \\
\hline $\begin{array}{l}\text { Thermal Storage } \\
\text { Power Density }\end{array}$ & $\begin{array}{l}\text { 1. Low thermal conductivity } \\
\text { 2. Trade-off between power and } \\
\text { energy } \\
\text { 3. Larger keff, } D_{\text {eff }}-->\text { larger pen. } \\
\text { depth --> more effectively } \\
\text { utilize the finite-thickness TES } \\
\text { 4. Cost for increasing k. }\end{array}$ & 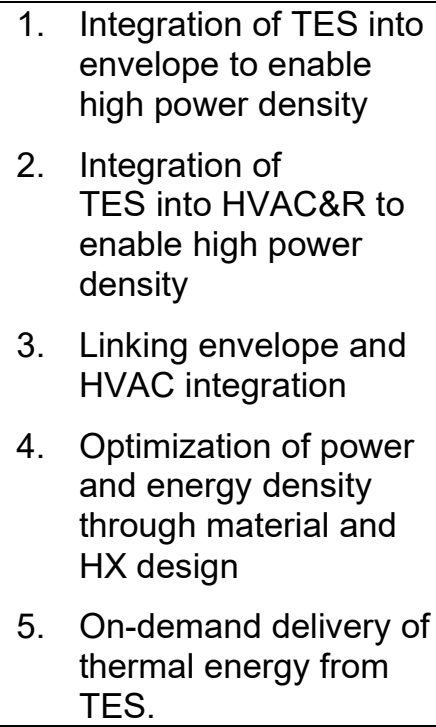 & \begin{tabular}{|l} 
1. $\begin{array}{l}\text { How do we } \\
\text { independently } \\
\text { control specific heat } \\
\text { and thermal } \\
\text { conductivity? }\end{array}$ \\
2. Fill the knowledge \\
gap of facilitating \\
decoupled energy \\
transfer and storage \\
(Cp and k) \\
3. Shape-stable, high-k \\
encapsulation of \\
solid/liquid PCM.
\end{tabular} & 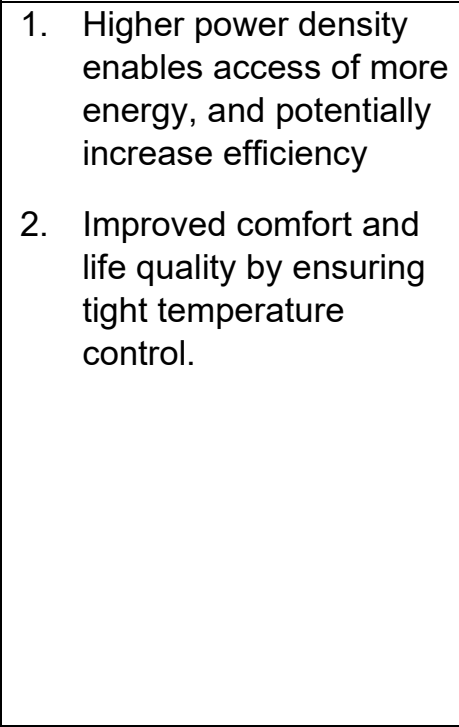 \\
\hline $\begin{array}{l}\text { Co-Design (TES } \\
\text { With System-Level } \\
\text { Optimal Design) }\end{array}$ & $\begin{array}{l}\text { 1. Current paradigm in building } \\
\text { thermal management does } \\
\text { not consider codesign of TES } \\
\text { with heat delivery or thermal } \\
\text { management } \\
\text { 2. Lack of available models on } \\
\text { this relatively disruptive } \\
\text { concept } \\
\text { 3. Where to strategically locate } \\
\text { the TES and delivery } \\
\text { components? }\end{array}$ & $\begin{array}{l}\text { 1. Comprehensive } \\
\text { modeling to consider } \\
\text { codesign of TES and } \\
\text { heat } \\
\text { pumping/delivery_this } \\
\text { seems to be a high } \\
\text { TRL topic } \\
\text { 2. Convert heat to other } \\
\text { useful energy forms } \\
\text { (electrical, chemical?) } \\
\text { at high efficiency. }\end{array}$ & $\begin{array}{l}\text { Convert heat to other } \\
\text { useful energy forms } \\
\text { (electrical, chemical?) at } \\
\text { high efficiency. }\end{array}$ & $\begin{array}{l}\text { Codesign could increase the } \\
\text { utilization of TES because it } \\
\text { can meet diverse thermal } \\
\text { loads and could also } \\
\text { accommodate various } \\
\text { available thermal and other } \\
\text { energy sources. }\end{array}$ \\
\hline
\end{tabular}




\begin{tabular}{|c|c|c|c|c|}
\hline Major Topics & Technological Barriers & $\begin{array}{l}\text { Transformational } \\
\text { Research Topics }\end{array}$ & $\begin{array}{l}\text { Potential Science } \\
\text { Impacts }\end{array}$ & $\begin{array}{l}\text { Impact on Energy } \\
\text { Technology }\end{array}$ \\
\hline & $\begin{array}{l}\text { 4. If there is excessive thermal } \\
\text { energy with high quality (high } \\
\text { temperature), how to } \\
\text { economically recover it to } \\
\text { electrical or other useful form } \\
\text { of energy (chemical?). }\end{array}$ & & & \\
\hline
\end{tabular}




\subsection{Lifetime}

Dr. Judith Vidal moderated the sessions on lifetime.

Highlights:

- TES is composed of multiple constituents integrated in a system.

- Thermal media: solid, liquid, gas, mixtures?

- Containments: mitigating damage through self-healing behavior of containments.

- For building applications, there are different operating temperatures based on requirements.

- Thermal cycling conditions, frequency, and $\Delta \mathrm{T}$.

- TES type: sensible, latent, thermochemical. The last two require different phases going through transformations (phase change, chemical reaction) that require nucleation and growth of the new phase or product.

- Lifetime barriers are identified as those that will impact the performance of the system. How to accurately predict lifetime? Experiments versus modeling? What parameters should be used to determine lifetime? Impact on energy density and power density?

- Journal articles, technical reports should provide details about chemistry, impurity levels, volume, surface, particle size, surface tension, wettability, cooling rate, and so on.

- Cost-effective systems are needed for envelopes for retrofits and repairs. Expected envelope lifetime could be at least around 30 years. Expected HVAC lifetime could be between 10 and 20 years. $^{2}$

- In multicomponent system, additives could help increase required self-healing reactivity once exposed to specific environments if a small rupture occurs in the system. Examples could be reaction with oxygen from atmosphere, or requiring curing using ultraviolet light.

- Retrofit panels are needed. Panels should be easy to handle, transport, and install. If costeffective, they could be replaced every 10 years.

- Modular subcomponents in HVAC and refrigeration systems should be easy to repair or remove for reinstallation.

Table 5 shows the summary of results of this breakout session as organized by Dr. Judith Vidal.

${ }^{2}$ https://www.nrel.gov/docs/fy110sti/50572.pdf 
Table 5. Lifetime: Major Topics, Technological Barriers, Transformational Research Topics, Potential Science Impacts, and Impact on Energy Technology

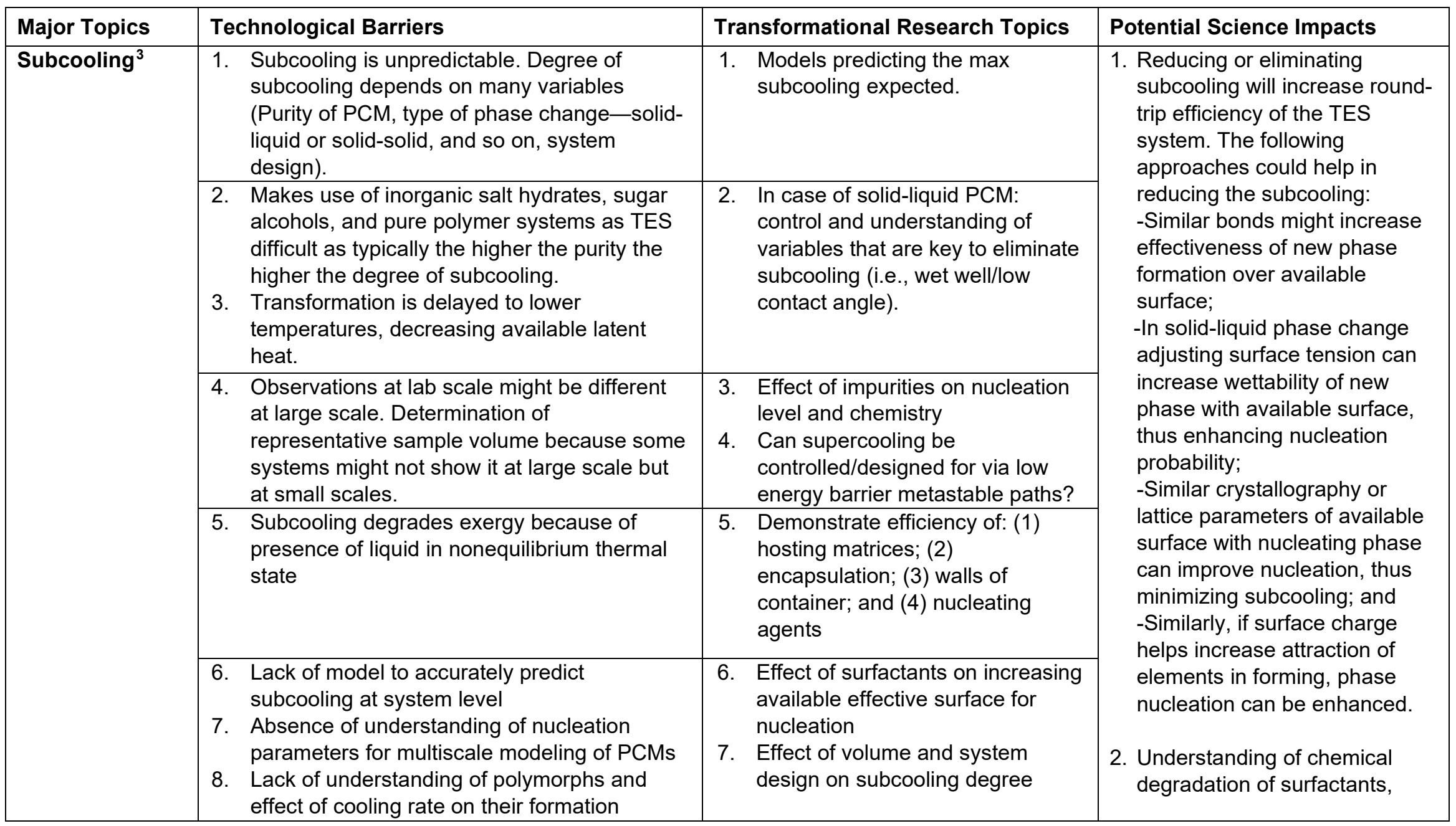

\footnotetext{
${ }^{3}$ While subcooling is usually perceived as part of utilization and efficiency, it was discussed in this breakout and the findings are also captured here.
} 


\begin{tabular}{|c|c|c|c|}
\hline Major Topics & Technological Barriers & Transformational Research Topics & Potential Science Impacts \\
\hline & $\begin{array}{l}\text { 9. Absence of understanding of thermal } \\
\text { conductivity impacting subcooling degree } \\
\text { 10. Lack of understanding main mechanisms for } \\
\text { nucleating agents and surface impact. Effect } \\
\text { of chemistry, surface charge, surface } \\
\text { morphology, crystallography, lattice } \\
\text { parameter, surface energy, contact angle, } \\
\text { available active area. }\end{array}$ & $\begin{array}{l}\text { 8. Effect of cooling rate } \\
\text { 9. Effect and control of incomplete } \\
\text { melting on subcooling by the } \\
\text { presence of previous unmelted } \\
\text { regions. Can other methods } \\
\text { trigger nucleation? }\end{array}$ & $\begin{array}{l}\text { available surfaces, or } \\
\text { nucleating agents will help } \\
\text { determine lifetime of system } \\
\text { 3. If subcooling does not reduce } \\
\text { latent heat and can be } \\
\text { controlled, could help tune } \\
\text { when the transition is needed. }\end{array}$ \\
\hline \multirow[t]{6}{*}{$\begin{array}{l}\text { Phase } \\
\text { Segregation }\end{array}$} & $\begin{array}{l}\text { 1. Decrease of energy density due to phase } \\
\text { segregation. Steep composition gradients, } \\
\text { and stratification in multicomponent systems } \\
\text { reduce thermal energy transfer. }\end{array}$ & \multirow{6}{*}{$\begin{array}{l}\text { 1. Confining reactant's space } \\
\text { (controlling volume) to minimize } \\
\text { diffusion length. Example: host } \\
\text { porous matrices and } \\
\text { encapsulation. } \\
\text { 2. Understanding nucleation and } \\
\text { growth kinetics to determine } \\
\text { minimum diffusion length needed } \\
\text { for given systems. } \\
\text { 3. Careful system design and } \\
\text { modeling to determine and } \\
\text { mitigate occurrence, severity, and } \\
\text { impact of phase segregation. } \\
\text { 4. Reliable accelerated testing } \\
\text { emulating real operating } \\
\text { conditions. }\end{array}$} & \multirow{6}{*}{$\begin{array}{l}\text { 1. Reliable models with } \\
\text { representative control volume } \\
\text { can accurately predict lifetime } \\
\text { when phase segregation is } \\
\text { controlled. } \\
\text { 2. Accurate data collection allows } \\
\text { small amount of reliable data } \\
\text { collected. } \\
\text { 3. Controlled experiments with } \\
\text { real operating conditions can } \\
\text { produce accurate results. } \\
\text { 4. Keeping main degradation } \\
\text { mechanisms active during } \\
\text { evaluation can help determine } \\
\text { real degradation mechanisms. } \\
\text { 5. Determination of synergy } \\
\text { among degradation } \\
\text { mechanisms can help } \\
\text { understand impact on lifetime. }\end{array}$} \\
\hline & $\begin{array}{l}\text { 2. Decrease in energy stored and released } \\
\text { because of incomplete reaction (latent and } \\
\text { thermochemical TES). Physical contact } \\
\text { among reactants is minimized. }\end{array}$ & & \\
\hline & $\begin{array}{l}\text { 3. Thermal cycling can increase phase } \\
\text { segregation. }\end{array}$ & & \\
\hline & 4. Energy capacity reduction & & \\
\hline & $\begin{array}{l}\text { 5. If components have very different densities, } \\
\text { slow cooling rates might increase phase } \\
\text { segregation. }\end{array}$ & & \\
\hline & $\begin{array}{l}\text { 6. Phase stratification with time is highly feasible } \\
\text { in multicomponent polymer systems having } \\
\text { different densities and melting points. }\end{array}$ & & \\
\hline
\end{tabular}




\begin{tabular}{|c|c|c|c|}
\hline Major Topics & Technological Barriers & Transformational Research Topics & Potential Science Impacts \\
\hline Mass Changes & $\begin{array}{l}\text { 1. Mass changes (loss/gain) degrade energy } \\
\text { density (e.g., high vapor pressure phases). } \\
\text { 2. Mass leakage reduce energy density by } \\
\text { decreasing extent of reactions. } \\
\text { 3. Phase solubility and dilution can decrease } \\
\text { energy density. }\end{array}$ & $\begin{array}{l}\text { 1. Design at the material and system } \\
\text { level to confine phases and } \\
\text { control mass losses/gain. } \\
\text { 2. Have excess of the reactants with } \\
\text { high vapor pressure (e.g., addition } \\
\text { of extra water in hydrate systems } \\
\text { above the stoichiometric value to } \\
\text { account for mass loss). }\end{array}$ & \begin{tabular}{|l} 
1. \\
Closed systems can eliminate \\
mass loss/gain and thus \\
eliminate concerns of energy \\
density decreasing. \\
2. In hydrate systems, water \\
addition control can mitigate \\
detrimental effect on energy \\
density and thus on lifetime. \\
3. Volumetric control at both at \\
material and system levels \\
can mitigate detrimental \\
impact of stresses on lifetime.
\end{tabular} \\
\hline $\begin{array}{l}\text { Phase } \\
\text { Decomposition }\end{array}$ & $\begin{array}{l}\text { Thermal decomposition of materials degrades } \\
\text { energy density. }\end{array}$ & $\begin{array}{l}\text { Selection and synthesis of stable } \\
\text { materials }\end{array}$ & \\
\hline
\end{tabular}




\subsection{Computational Aspects}

Two broad computational aspect themes emerged:

1. How can improvements in materials modeling, along with parallel improvements in synthesis and characterization, be leveraged to develop and improve thermal battery materials?

2. How can we develop algorithms (e.g., machine learning) to better manage thermal storage assets and their quirks, as well as understand economic impacts of new storage technologies?

A common hurdle also emerged - the need for community data to validate computer models.

Table 6 shows the summary of results of this breakout session as organized by Dr. Anubhav Jain. 
Table 6. Computational Aspects: Major Topics, Technological Barriers, Transformational Research Topics, Potential Science Impacts, and Impact on Energy Technology

\begin{tabular}{|c|c|c|c|c|}
\hline Major Topics & Technological Barriers & $\begin{array}{l}\text { Transformational } \\
\text { Research Topics }\end{array}$ & $\begin{array}{l}\text { Potential Science } \\
\text { Impacts }\end{array}$ & $\begin{array}{l}\text { Impact on Energy } \\
\text { Technology }\end{array}$ \\
\hline $\begin{array}{l}\text { Computational } \\
\text { Discovery/Materials } \\
\text { Modeling }\end{array}$ & $\begin{array}{l}\text { 1. Need for data sets to } \\
\text { validate methods, whether } \\
\text { that is theoretical models } \\
\text { or machine learning } \\
\text { methods } \\
\text { 2. Lack of dedicated } \\
\text { funding for data set } \\
\text { generation } \\
\text { 3. "ImageNet" for thermal } \\
\text { sciences-or "Thermal } \\
\text { Materials Genome" } \\
\text { 4. Lack of high-throughput } \\
\text { synthesis opportunities } \\
\text { 5. Use Natural Language } \\
\text { Processing to assist? } \\
\text { 6. Need multiscale } \\
\text { modeling methods to } \\
\text { integrate work from } \\
\text { different theories all the } \\
\text { way to building scale. }\end{array}$ & $\begin{array}{l}\text { 1. Ability to use } \\
\text { computational screening to } \\
\text { accelerate experimental } \\
\text { work } \\
\text { 2. What can be efficiently } \\
\text { modeled, and what is } \\
\text { better to simply perform } \\
\text { experiments on (e.g., can } \\
\text { we screen the space of salt } \\
\text { hydrates/dehydrogenation } \\
\text { reactions/organic PCMs } \\
\text { computationally)? } \\
\text { 3. Investigate the kinetics } \\
\text { of thermal storage via a } \\
\text { suite of computational } \\
\text { methods. }\end{array}$ & $\begin{array}{l}\text { 1. Basic research into } \\
\text { modeling surface } \\
\text { processes/surface } \\
\text { adsorption-important to } \\
\text { nanofluids } \\
\text { 2. Basic research into } \\
\text { modeling heterogeneous } \\
\text { catalysis to promote } \\
\text { nucleation in PCMs } \\
\text { 3. Modeling of reaction } \\
\text { kinetics } \\
\text { 4. Ability to help } \\
\text { characterize 3D structure } \\
\text { of thermal storage } \\
\text { materials (e.g., as a } \\
\text { function of cycling) } \\
\text { 5. Predict and prevent } \\
\text { degradation mechanisms. }\end{array}$ & $\begin{array}{l}\text { 1. More efficient use of } \\
\text { research resources } \\
\text { 2. Decouple data collection } \\
\text { and method } \\
\text { development/algorithm } \\
\text { development } \\
\text { 3. Accelerated design of } \\
\text { novel materials solutions to } \\
\text { thermal energy problems } \\
\begin{array}{l}\text { 4. Improved ability to } \\
\text { diagnose and fix issues in } \\
\text { current materials solutions. }\end{array}\end{array}$ \\
\hline $\begin{array}{l}\text { Better Managing Thermal } \\
\text { Technology Materials }\end{array}$ & $\begin{array}{l}\text { Data sets to train and } \\
\text { validate algorithms and } \\
\text { models for thermal } \\
\text { technology management } \\
\text { (e.g., experimental data on } \\
\text { deployed systems or } \\
\text { prototype systems). }\end{array}$ & $\begin{array}{l}\text { 1. Application of machine } \\
\text { learning to control thermal } \\
\text { management systems } \\
\text { 2. Prevent need for } \\
\text { undercooling (e.g., stop } \\
\text { before fully melt) }\end{array}$ & $\begin{array}{l}\text { 1. Can guide the } \\
\text { development of what types } \\
\text { of thermal technologies are } \\
\text { most needed } \\
\text { 2. Tunable phase change } \\
\text { temperature? } \\
\text { 3. Reduced degradation? }\end{array}$ & $\begin{array}{l}\text { 1. More efficient use of } \\
\text { thermal batteries } \\
\text { 2. More accurate } \\
\text { economic estimates of } \\
\text { Levelized Cost of Storage } \\
\text { (LCOS). }\end{array}$ \\
\hline
\end{tabular}




\begin{tabular}{|l|l|l|l|l|}
\hline Major Topics & Technological Barriers & $\begin{array}{l}\text { Transformational } \\
\text { Research Topics }\end{array}$ & $\begin{array}{l}\text { Potential Science } \\
\text { Impacts }\end{array}$ & $\begin{array}{l}\text { Impact on Energy } \\
\text { Technology }\end{array}$ \\
\hline & $\begin{array}{l}\text { 3. Degradation } \\
\text { management } \\
\text { 4. Ability to integrate } \\
\text { potential next-generation } \\
\text { tech into building modeling } \\
\text { software (thermal switches, } \\
\text { dynamically tunable PCM, } \\
\text { novel materials with exotic } \\
\text { properties). }\end{array}$ & $\begin{array}{l}\text { 5. Improved kinetics? } \\
\text { 6. Guide the science so we } \\
\text { unneeded technologies. } \\
\text { unnecoling? }\end{array}$ \\
\hline
\end{tabular}




\section{Recommendations}

After going over the discussion points in each breakout session, we identified the following recommendations:

1. Convene a team of researchers to create a common definition of TES efficiency;

2. Determine methods to estimate TES efficiency;

3. Determine effective ways to improve the utilization of TES;

4. Develop cost-effective and reliable PCMs (solid-liquid, solid-solid) and insulation materials with dynamic properties to enable tunable storage and thermal switches;

5. Improve the effectiveness of heat and mass transport to enable improved spatial and directional control of thermal energy;

6. Investigate methods to improve nucleation of phases when PCMs are used for TES;

7. Control segregation of phases when PCMs are used for TES;

8. Explore ways to screen the space of salt hydrates/dehydrogenation reactions/organic PCMs computationally;

9. Develop algorithms (e.g., machine learning) to better manage thermal storage assets and understand economic impacts of new storage technologies;

10. Develop data sets to validate theoretical models or machine learning methods; and

11. A more general recommendation is to create a larger effort with a consortium of national laboratories, universities, and other research organizations on TES. 


\section{References}

U.S. Energy Information Administration. 2019. Annual Energy Outlook 2019. "Reference Case Simulations." Washington, D.C. https://www.eia.gov/outlooks/aeo/.

U.S. Department of Energy. 2019. Grid-interactive Efficient Buildings Technical Report Series: Heating, Ventilation, and Air Conditioning (HVAC); Water Heating; Appliances; and

Refrigeration. Washington, D.C. https://www1.eere.energy.gov/buildings/pdfs/75473.pdf. 


\section{Appendix A-Agenda}

Workshop on Fundamental Needs for Dynamic and Interactive Thermal Storage Solutions for Buildings

LBNL, Berkeley, California

November 19-20, 2019

Bld. 50 Auditorium

Table A-1. November 19: 8 a.m.-5:30 p.m.

\begin{tabular}{|c|c|c|}
\hline 8:00 a.m. & Registration One Cyclotron Road, 50 Auditorium, Be & keley, CA 94720 \\
\hline 8:30 a.m. & Welcome (LBNL) & $\begin{array}{l}\text { Mike Witherell, Lab Director, } \\
\text { LBNL }\end{array}$ \\
\hline 8:40 a.m. & $\begin{array}{l}\text { Invited Talk: Scientific and Technological } \\
\text { Challenges in Thermal Storage (DOE) } \\
\text { Why are we here? Review of goals/objectives, } \\
\text { challenges, R\&D needs, and opportunities }\end{array}$ & $\begin{array}{l}\text { Karma Sawyer, Program } \\
\text { Manager for Emerging } \\
\text { Technologies, DOE }\end{array}$ \\
\hline 9:10 a.m. & $\begin{array}{l}\text { Invited Talk: Role of Thermal Storage in Zero Net } \\
\text { Energy Buildings (CEC) }\end{array}$ & Robin Goodhand, CEC \\
\hline 9:30 a.m. & Invited Talk: History of Electrochemical Storage & $\begin{array}{l}\text { Robert Kostecki, Scientific } \\
\text { Division Director, Energy } \\
\text { Storage Group, LBNL }\end{array}$ \\
\hline 9:50 a.m. & Networking Break & \\
\hline 10:40 a.m. & $\begin{array}{l}\text { Invited Talk: Evolution, Progress, and Challenges } \\
\text { of Thermal Storage in Concentrated Solar Power }\end{array}$ & $\begin{array}{l}\text { Judith Vidal, Group Manager, } \\
\text { Building Energy Science, } \\
\text { NREL }\end{array}$ \\
\hline 11:00 a.m. & Invited Talk: Computational Material Discovery & $\begin{array}{l}\text { Anubhav Jain, Staff Scientist, } \\
\text { LBNL }\end{array}$ \\
\hline 11:20 a.m. & $\begin{array}{l}\text { Invited Talk: Challenges with Current } \\
\text { Characterization Techniques for Thermal Energy } \\
\text { Storage Materials }\end{array}$ & $\begin{array}{l}\text { Kyle Gluesenkamp and Navin } \\
\text { Kumar, ORNL }\end{array}$ \\
\hline 11:40 a.m. & $\begin{array}{l}\text { Invited Talk: New Characterization Techniques for } \\
\text { Thermal Storage Material }\end{array}$ & Eli Rotenberg, LBNL \\
\hline 12:00 p.m. & $\begin{array}{l}\text { Framing Discussion for Breakout Sessions } \\
\text { Discuss the flow of the day. } \\
\text { Expected outcomes }\end{array}$ & $\begin{array}{l}\text { Organizers (Suman and } \\
\text { Marcus) }\end{array}$ \\
\hline
\end{tabular}




\begin{tabular}{|c|c|c|}
\hline $\begin{array}{l}\text { 12:10-1:00 } \\
\text { p.m. }\end{array}$ & $\begin{array}{l}\text { Innovation Approach and the Intersection of } \\
\text { Materials Science, Measuring Science, and } \\
\text { Integration Science } \\
\text { Working Lunch }\end{array}$ & $\begin{array}{l}\text { Discussions with Ravi Prasher } \\
\text { (Associate Lab Director, } \\
\text { LBNL) and Roderick Jackson } \\
\text { (Lab Program Manager, } \\
\text { NREL) }\end{array}$ \\
\hline \multirow[t]{4}{*}{$\begin{array}{l}\text { 1:00-3:00 } \\
\text { p.m. }\end{array}$} & $\begin{array}{l}\text { Breakout A: Efficiency } \\
\text { Location: } 50-\text { Auditorium }\end{array}$ & Moderator: Judith Vidal \\
\hline & $\begin{array}{l}\text { Breakout B: Utilization } \\
\text { Location: } 50 A-5132\end{array}$ & $\begin{array}{l}\text { Moderator: Chris Dames, Prof. } \\
\text { of Mech Engineering, UC } \\
\text { Berkeley }\end{array}$ \\
\hline & $\begin{array}{l}\text { Breakout C: Lifetime } \\
\text { Location: } 70 A-3377\end{array}$ & $\begin{array}{l}\text { Moderator: Gao Liu, Group } \\
\text { Leader for Applied Energy } \\
\text { Material }\end{array}$ \\
\hline & $\begin{array}{l}\text { Breakout D: Computational Discovery of Thermal } \\
\text { Storage Materials } \\
\text { Location: } 70-191\end{array}$ & Moderator: Anubhav Jain \\
\hline 3:00 p.m. & $\begin{array}{l}\text { Networking Break } \\
\text { Location: } 50 \text {-Auditorium }\end{array}$ & \\
\hline $\begin{array}{l}\text { 4:00-5:30 } \\
\text { p.m. }\end{array}$ & Continuation of Breakout Sessions & \\
\hline 5:30 p.m. & Wrap Up/Adjourn & \\
\hline 5:45 p.m. & Travel to No-Host Dinner & \\
\hline
\end{tabular}


Table A-2. November 20: 8 a.m.-12:30 p.m.

Bld. 50 Auditorium

\begin{tabular}{|c|c|c|}
\hline 8:00 a.m. & $\begin{array}{l}\text { Overview of Day } 1 \\
\text { Location: } 50 \text {-Auditorium }\end{array}$ & \\
\hline 8:10 a.m. & $\begin{array}{l}\text { Invited Talk: NSF Perspective on Thermal } \\
\text { Energy Storage }\end{array}$ & $\begin{array}{l}\text { Ying Sun, Program Director, } \\
\text { Thermal Transport Processes } \\
\text { (ENG/CBET), NSF }\end{array}$ \\
\hline \multirow[t]{4}{*}{$\begin{array}{l}8: 30-9: 30 \\
\text { a.m. }\end{array}$} & $\begin{array}{l}\text { Breakout A: Efficiency } \\
\text { Location: 50-Auditorium (Left Corner) }\end{array}$ & Moderator: Judith Vidal \\
\hline & $\begin{array}{l}\text { Breakout B: Utilization } \\
\text { Location: } 50 B-2222\end{array}$ & $\begin{array}{l}\text { Moderator: Chris Dames, Prof. } \\
\text { of Mech Engineering, UC } \\
\text { Berkeley }\end{array}$ \\
\hline & $\begin{array}{l}\text { Breakout C: Lifetime } \\
\text { Location: 50-Auditorium (Right Corner) }\end{array}$ & $\begin{array}{l}\text { Moderator: Gao Liu, Group } \\
\text { Leader for Applied Energy } \\
\text { Material }\end{array}$ \\
\hline & $\begin{array}{l}\text { Breakout D: Computational Discovery of } \\
\text { Thermal Storage Materials } \\
\text { Location: } 70-191\end{array}$ & Moderator: Anubhav Jain \\
\hline $\begin{array}{l}\text { 9:30-10:00 } \\
\text { a.m. }\end{array}$ & Break & \\
\hline 10:00 a.m. & $\begin{array}{l}\text { Main Technical Findings, Roadmap from } \\
\text { Breakout A } \\
\text { Location: } 50 \text {-Auditorium }\end{array}$ & \\
\hline 10:35 a.m. & $\begin{array}{l}\text { Main Technical Findings, Roadmap from } \\
\text { Breakout B } \\
\text { Location: } 50 \text {-Auditorium }\end{array}$ & \\
\hline 11:10 a.m. & $\begin{array}{l}\text { Main Technical Findings, Roadmap from } \\
\text { Breakout C } \\
\text { Location: } 50 \text {-Auditorium }\end{array}$ & \\
\hline 11:45 p.m. & $\begin{array}{l}\text { Main Technical Findings, Roadmap from } \\
\text { Breakout D } \\
\text { Location: } 50 \text {-Auditorium }\end{array}$ & \\
\hline 12:20 p.m. & Closing Remarks & \\
\hline 12:30 p.m. & Adjourn & \\
\hline
\end{tabular}




\section{Appendix B-Participants}

Table B-1. List of Participants Who Attended the Workshop

\begin{tabular}{|l|l|l|l|}
\hline Participant & Affiliation & Participant & Affiliation \\
\hline Terry Andrews & CALMAC Corporation & Anubhav Jain & LBNL \\
\hline Nick AuYeung & Oregon State University & Nelson James & DOE \\
\hline Rohini Bala Chandra & University of Michigan & Sumanjeet Kaur & LBNL \\
\hline Debjyoti Banerjee & Texas A\&M University & Robert Kostecki & LBNL \\
\hline Marcus Bianchi & NREL & Navin Kumar & ORNL \\
\hline Kaushik Biswas & ORNL & Jaeho Lee & UC Irvine \\
\hline Van Carey & UC Berkeley & Like Li & $\begin{array}{l}\text { Mississippi State } \\
\text { University }\end{array}$ \\
\hline Dhanesh Chandra & $\begin{array}{l}\text { University of Nevada, } \\
\text { Reno }\end{array}$ & Gao Liu & LBNL \\
\hline Chien-Hua Chen & $\begin{array}{l}\text { Advanced Cooling } \\
\text { Technologies, Inc. }\end{array}$ & Sven Mumme & DOE \\
\hline Renkun Chen & UC San Diego & Wale Odukomaiya & NREL \\
\hline Jinxing Chen & UC Riverside & Mary Ann Piette & LBNL \\
\hline Chris Church & $\begin{array}{l}\text { Applied Research } \\
\text { Associates }\end{array}$ & Ravi Prasher & LBNL \\
\hline Jun Cui & Ames Laboratory & Vi Rapp & LBNL \\
\hline Chris Dames & UC Berkeley & Eli Rotenberg & LBNL \\
\hline Spencer Dutton & LBNL & Thomas Russell & LBNL \\
\hline Nicola Ferralis & MIT & Karma Sawyer & DOE \\
\hline Srinivas Garimella & Georgia Tech & Som Shrestha & ORNL \\
\hline David Ginley & NREL & Ying Sun & NSF \\
\hline Adam Gladen & $\begin{array}{l}\text { North Dakota State } \\
\text { University }\end{array}$ & $\begin{array}{l}\text { Rajeev Surendran } \\
\text { Assary }\end{array}$ & $\begin{array}{l}\text { Argonne National } \\
\text { Laboratory }\end{array}$ \\
\hline Kyle Gluesenkamp & ORNL & $\begin{array}{l}\text { Paulo Cesar Tabares } \\
\text { Velasco }\end{array}$ & $\begin{array}{l}\text { Colorado School of } \\
\text { Mines }\end{array}$ \\
\hline Robin Goodhand & CEC & Judith Vidal & NREL \\
\hline Shan Hu & lowa State University & Jialai Wang & $\begin{array}{l}\text { The University of } \\
\text { Alabama }\end{array}$ \\
\hline Yongjie Hu & UCLA & NREL \\
\hline Roderick Jackson & NREL & Jason Woods & \\
\hline
\end{tabular}




\section{Appendix C-Invitation Sent to Prospective Participants}

We prepared and sent the following message to prospective participants starting in August 2019.

Dear Invitee:

We are pleased to invite you to the Workshop on Fundamental Needs for Dynamic and Interactive Thermal Storage Solutions for Buildings, jointly organized by Lawrence Berkeley National Laboratory (LBNL) and the National Renewable Energy Laboratory (NREL), to take place on Nov 19-20 in Berkeley, CA. Details are provided below.

As space is limited, your confirmation of attendance will be greatly appreciated. Please complete the online registration for the workshop at https://sites.google.com/lbl.gov/buildingsworkshop/. Please contact us if you have any questions. We look forward to hearing from you and hope that you will be available to participate in the event.

Best Regards,

Sumanjeet Kaur (LBNL) and Marcus Bianchi (NREL)

\section{Workshop on Fundamental Needs for Dynamic and Interactive Thermal Storage Solutions for Buildings}

Driven by the deployment of variable renewable energy capacity at a large scale, energy storage systems have turned into an important element to supply on-demand electricity. Most existing energy storage solutions are electrochemical (batteries) or electromechanical (flywheels, pumped storage). In buildings, since $50 \%$ of the energy consumed is for thermal end uses, TES can also play an important role in facilitating a balanced energy system that is efficient, resilient, and affordable. While readily available, deployment of traditional latent energy thermal storage in buildings is still limited primarily because it charges and discharges passively in response to ambient temperatures and it can only shift to off-peak hours either in heating or cooling modes, not both. Additionally, most PCMs suffer from issues such as supercooling, broad transition temperatures, low energy density, poor heat transfer, degradation with cycling, and high prices. All these problems collectively make existing TES inefficient and expensive. Therefore, it is imperative to develop truly disruptive thermal storage solutions that enable control of charging and discharging and address the major shortcomings of existing technologies.

Lawrence Berkeley National Laboratory and the National Renewable Energy Laboratory are inviting a group of researchers with backgrounds in materials science, thermal science, building science, electrochemistry, and organic chemistry to discuss and investigate dynamic and interactive TES solutions and its adjacent systems for building applications. Program managers from DOE and CEC will participate in the workshop. 
The aim of the workshop is to revisit recent breakthroughs and identify future research opportunities in scientific areas related to:

1. Dynamically tunable thermal storage materials that can modify their switching temperature or characteristics to operate optimally in both summer and winter

2. Thermal circuits elements (analogous to electrical circuits) diodes, switches, and transistors, which could control directional heat and mass transfer and thus provide management over the timing of charging or discharging

3. Characterization tools and techniques to understand fundamental issues such as supercooling, non-equilibrium phases, slow kinetics, and poor cyclability in TES materials

4. Expedite discovery of new materials using computational materials design for thermal energy solutions, combinatorial synthesis, and high throughput characterization.

Additional details will follow as we finalize the agenda of the workshop.

Sincerely,

Organizers

Lead: Sumanjeet "Suman" Kaur (LBNL) and Marcus Bianchi (NREL)

Support: Ravi Prasher (LBNL), Roderick Jackson (NREL) and Judith Vidal (NREL) 